\title{
ALKALINE FACTOR IN CEMENTS WITH GLASS POWDER
}

\author{
Victor Shevchenko ${ }^{1, *}$, Galyna Kotsay ${ }^{1}$
}

DOI: dx.doi.org/10.23939/chcht11.01.099

\begin{abstract}
The effect of alkaline component in glass powder on the total alkaline content of cement-glass mixtures, which is limited by standards, has been investigated by means of $\mathrm{pH}$-metry, titration and different extragents. Using experimental and calculated results concerning alkaline activity of glass powder it is possible to develop chemical structure of the cement composites which would meet the standards in regard to total alkaline content.
\end{abstract}

Key words: alkaline factor, Portland cement, cementglass mixtures, glass powder, extraction of alkali ions.

\section{Introduction}

Last decade a great number of publications examined the possibility of using glass wastes instead of cement. However, glass wastes usage, especially container glass, has special peculiarity - high alkali content (13-15 wt \%). Such quantity of alkali in glass is a compromise between positive effect on glass melting temperature reduction and its technological and operational properties. At the same time the alkali content in cement is limited by the fact that small quantity of alkali $(0.2-0.3 \%)$ decreases the temperature of liquid phase formation in the high-temperature zone of the cement furnace and accelerates belite $\left(\mathrm{C}_{2} \mathrm{~S}\right)$ dissolving in the melt. However, the increase in $\mathrm{R}_{2} \mathrm{O}$ quantity till $0.6 \%$ and higher leads to the isomorphic substitution of $\mathrm{Ca}^{2+}$ ions in minerals for $\mathrm{Na}^{+}$and $\mathrm{K}^{+}$ions. They compact the crystal lattice of belite and impede formation of alite [1]. If we additionally consider the alkaline corrosion occurred while contact between alkali and filler in concrete, the result is a damage of concrete constructions during long-

\footnotetext{
${ }^{1}$ Warsaw University of Technology, Branch at Plock

17 Lukashevicha St., PL-09400 Plock, Poland;

*chewchenko4@yahoo.com

(c) Shevchenko V., Kotsay G., 2017
}

term operation. To protect concrete from alkaline corrosion the fine-grinded additives of active silica are introduced capable to neutralize alkali at the initial stage of hardening. Such operation allows increasing the alkali content to $2 \%$. When analyzing the chemical compositions of Portland cement investigated by different authors [2-9] we observe the quantity of $\mathrm{R}_{2} \mathrm{O}$ varied from 0.6 to $1.0 \%$. The majority of authors suggest substituting Portland cement for fine-grinded glass powder in the amount of $20-50 \%$ and ignoring the effect of alkaline factor. However, taking into account the high alkali content in glass and high specific surface of glass powder we may forecast the great effect of alkali component on the total alkali content in the cement-glass mixture. The chemical compositions of Portland cement and glass can considerably vary. Thus it is necessary to take into account the alkali content and alkali activity $(A i)$ of every component while creating the cement-glass mixture.

\section{Experimental}

Portland cement CEM I 32.5R produced in accordance with European standard EN 197-1:2002, container glass of three types, and pozzolanic mineral additives (Table 1) were used for the investigations.

Selected glass wastes were grinded in jaw crusher, then in ball mill and purified from metal particles by magnetic separation. The obtained glass powder was sifted through the standard sieves. The fractional composition of glass powder is given in Table 2.

In connection with the fact that time of contact between glass and water is limited (see below), the most available measurement of alkali content is by using $\mathrm{pH}$ meter. H198127 pH-meter produced by HANNA firm has temperature automatic correlation, indicator of equilibrium and measurement error of $+/-0.1$. In parallel we determined $\mathrm{R}_{2} \mathrm{O}$ quantity in the solution using titration method $(0.01 \mathrm{~N} \mathrm{HCl})$ after alkali extraction by water. 
Chemical composition and specific surface areas of the investigated materials, wt \%

\begin{tabular}{|l|c|c|c|c|c|c|}
\hline \multirow{2}{*}{ Oxides } & \multicolumn{3}{|c|}{ Glass } & \multirow{2}{*}{ Cement } & \multirow{2}{*}{ Microsilica } & \multirow{2}{*}{ Fly ash } \\
\cline { 2 - 4 } & colorless & brown & green & & & \\
\hline $\mathrm{SiO}_{2}$ & 72.20 & 72.15 & 71.80 & 21.40 & 94.6 & 59.50 \\
\hline $\mathrm{Al}_{2} \mathrm{O}_{3}$ & 1.80 & 1.75 & 1.80 & 5.70 & 2.10 & 18.90 \\
\hline $\mathrm{CaO}$ & 10.10 & 10.00 & 10.97 & 64.50 & 0.44 & 13.20 \\
\hline $\mathrm{MgO}$ & 1.65 & 1.55 & 1.00 & 1.80 & 0.62 & 0.20 \\
\hline $\mathrm{R}_{2} \mathrm{O}$ & 13.80 & 14.00 & 13.35 & 0.70 & 1.14 & 0.70 \\
\hline $\mathrm{Fe}_{2} \mathrm{O}_{3}$ & 0.04 & 0.20 & 0.45 & 3.30 & 1.10 & 5.40 \\
\hline $\mathrm{Cr}_{2} \mathrm{O}_{3}$ & 0.01 & 0.03 & 0.25 & - & - & - \\
\hline $\mathrm{SO}_{3}$ & 0.40 & 0.32 & 0.38 & 2.60 & - & 1.60 \\
\hline${\text { Specific surface areas, } \mathrm{m}^{2} / \mathrm{g}}$ & 0.22 & 0.20 & 0.21 & 0.36 & 15 & 0.43 \\
\hline
\end{tabular}

Table 2

Fractional composition of glass powder

\begin{tabular}{|l|c|c|c|c|}
\hline \multirow{2}{*}{ Glass } & \multicolumn{4}{|c|}{ Glass grain sizes, mm } \\
\cline { 2 - 5 } & 0.125 & 0.075 & \multicolumn{4}{c|}{0.063} & $<0.063$ \\
\cline { 2 - 5 } & \multicolumn{4}{|c|}{$\%$} \\
\hline Colorless & 19.0 & 19.6 & 22.2 & 46.3 \\
\hline Brown & 26.8 & 21.9 & 8.8 & 42.5 \\
\hline Green & 21.5 & 22.9 & 16.5 & 39.0 \\
\hline
\end{tabular}

\section{Results and Discussion}

It is known that alkali content in cement may be determined as: total alkali content, content of alkali soluble in water and content of "active" alkali corresponding to $\mathrm{Na}_{2} \mathrm{O}_{\text {eq }}$ quantity passed to the solution at the various stages of hydration [10]. The first one may be determined by usual chemical analysis; the second one in accordance with British standard BS 4550 II. Concerning the determination of "active" alkali in the glass powder the information about such method is absent in the literature. Therefore, we suggest introducing the idea of two levels of alkaline activity for glass powder: the first level is an alkaline component of glass particles surface that contacts with water, transfers into a solution and participates in cement hydration during pre-induction period, and the second level means alkaline component in the bulk of glass particles participating in Alkali-SilicaReaction ("ASR") during post-induction period of hydration.

The determination of cement and glass alkali activity is complicated by the fact that two processes occur at the same time while adding water to cement-glass mixture:

- extraction of alkali ions from the glass grains surface and formation of sodium and potassium hydroxides according to the reaction (1);

$$
\begin{array}{ll}
\mathrm{Na}_{2} \mathrm{SiO}_{3}+\mathrm{H}_{2} \mathrm{O} \rightarrow \underset{\text { glass }}{\rightarrow} & \mathrm{SiO}_{2}+2 \mathrm{NaOH}(\mathrm{KOH}) \\
\text { S-gel } & \text { solution }
\end{array}
$$

- cement hydration accompanied by alkali medium formation due to potassium hydroxide.

$$
\underset{\text { alite }}{2\left(3 \mathrm{CaOSiO}_{2}\right)}+6 \mathrm{H}_{2} \mathrm{O} \rightarrow \underset{\mathrm{CSH} \text {-gel }}{3 \mathrm{CaO}} 2 \mathrm{SiO}_{2} \cdot 3 \mathrm{H}_{2} \mathrm{O}+3 \mathrm{Ca}(\mathrm{OH})_{2}
$$

The reaction (1) proceeds with high rate and is completed by hydration of glass surface, i.e. hydrogen cations fill place of alkali cations and block diffusion of alkali cations from the deep layers of glass under the condition that hydration is carried out at room temperature. The peculiarity of the reaction (1) is the fact that alkali cations are bound by ionic bond with low value of activation energy, therefore they easily leave their places. This fact considerably facilitates their extraction.

The result of cement hydration, reaction (2), is the formation of $\mathrm{CSH}$-gel and mixture $\mathrm{Ca}(\mathrm{OH})_{2}+\mathrm{ROH}$ with $\mathrm{pH}=13-14$ at the beginning of pre-induction period [1] The increase in alkalinity promotes bonding sulfates in ettringitu [11, 12], however the morphology and microstructure of $\mathrm{CSH}$-gel phase vary and thus decrease cement mortar strength during its hardening [12]. Moreover, $\mathrm{Ca}(\mathrm{OH})_{2}$ affects the glass as a reagent of the second group to the reaction (3), destroys silica-oxygen skeleton and transforms silicon dioxide into stable anions $\mathrm{SiO}_{4}{ }^{4-}, \mathrm{Si}_{2} \mathrm{O}_{5}{ }^{2-}, \mathrm{SiO}_{3}{ }^{2-}$, which are non-polymerizable in the alkaline medium [13].

$$
\begin{gathered}
\left(\mathrm{Ca}(\mathrm{OH})_{2}+\mathrm{ROH}\right)+\mathrm{SiO}_{2} \\
\text { in the cement }
\end{gathered} \underset{\text { glass }}{\mathrm{CaO} \mathrm{R}} \mathrm{O} \mathrm{SiO}_{2} \mathrm{nH}_{2} \mathrm{O}
$$

The quantity of $\mathrm{CNKSH}$-gel is very small on the surface of glass grains, because the reaction (3) proceeds with low rate at room temperature. However, the chemical 
composition of this gel differs from that of CSH-gel by the presence of alkali component. This fact is confirmed by the investigations about the effect of the glass powder on the hydration of Portland cement using microcalorimetry [14]. At the beginning of hydration preinduction period, starting from the moment of cement and water contact, the rate of heat release is higher by 10-25\% compared with that of the sample without glass. It means that alkali activity of glass powder acts as a catalyst, accelerator of hydration at the beginning of preinduction period.

Taking into account that several parallel reactions proceed at the beginning of hydration, it is advisable to examine these processes separately and determine the alkali activity of every component in the cement composite. While analyzing various possibilities to determine alkali activity we came to conclusion that $\mathrm{pH}$ metry is the most optimal method for this purpose. Taking into account that water is useless for extraction because $\mathrm{Ca}(\mathrm{OH})_{2}$ is formed according to the reaction (2)) we used ethyl alcohol.

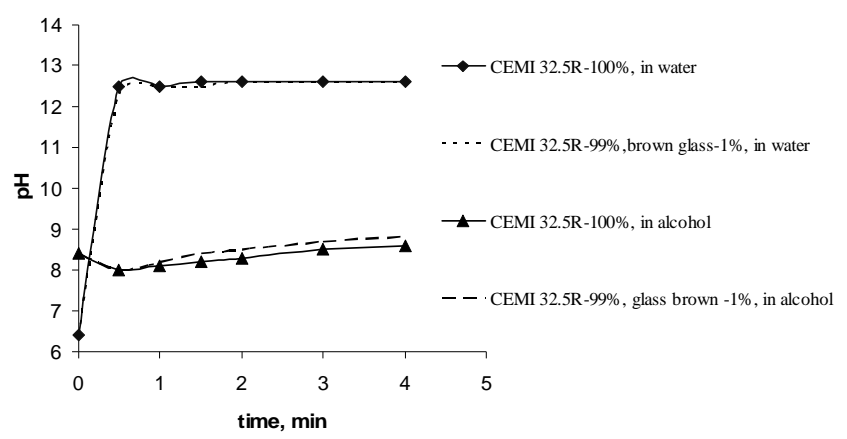

Fig. 1. Dependence of solutions pH on time of contact between Portland cement and glass with different extraction agents

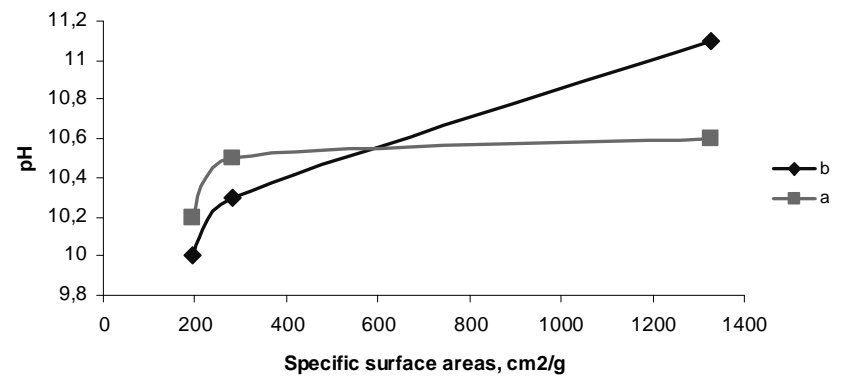

Fig. 2. Dependence of solutions $\mathrm{pH}$ on the specific surface of green glass powder: titration method (a) and $\mathrm{pH}$ - metry (b)

For water the $\mathrm{pH}$ values sharply increases from 6.4 to 12.6 during $30 \mathrm{~s}$. Further the value is constant and there is no difference between pure cement and the cement mix with glass powder. Slight increase in $\mathrm{pH}$ value for pure cement is explained by extraction of its alkali component by alcohol. The partial exchange of cement for glass powder favors the increase of $\mathrm{pH}$ value due to alkaline presence in glass. Though the difference is within error range, the general tendency of higher $\mathrm{pH}$ value for the composite is observed.

The amount of extracted alkali ions, hence solution $\mathrm{pH}$, considerably depends on fractional composition and specific surface of glass powder. Therefore it is necessary to determine which fraction has the greatest effect on solutions pH. Fig. 2 represents the dependence of solutions $\mathrm{pH}$ (determined by different methods) on the specific surface of glass powder taking green glass as an example.

The obtained dependence (Fig. 2) shows: i) the amount of extracted alkaline increases with the increase of specific surface for both methods; ii) using the titration method we observe only weak tendency of growth, because $\mathrm{pH}$ variations are within the range of method accuracy. Using $\mathrm{pH}$-metry we observe the variations considerably exceeding the measurement accuracy. Moreover, both methods show that the greatest changes are observed while using the fraction $<0063 \mathrm{~mm}\left(\sim 0.026 \mathrm{~m}^{2} / \mathrm{g}\right)$, therefore it is necessary to use just this fraction for the further investigations. We carried out special investigations and grinded the above-mentioned fraction into finer fractions via sedimentation in alcohol. We established that $\mathrm{pH}$ level is determined by the finest (powder-like) fraction. Thus it should be noted that while using any fractions, the powderlike fraction covers the surface of glass grains and contributes to the total $\mathrm{pH}$ level.

Taking into account that actually only cations of grain surface participate in the first stage of hydration during pre-induction period, it is possible to determine the share of these cations relative to the total alkali content. For this purpose we examined the dependence of $\mathrm{Na}_{2} \mathrm{Oeq}$ quantity passed into the solution during $30 \mathrm{~s}$ on the ratio glass/water (Table 3). We used the titration method and took glass powder as an example.

Hydroxyl groups concentration is sharply changed at the ratio glass/water equal to 0.025 (1:40) (Table 3). At the same time the share of surface cations is about $6 \%$. We examined the obtained dependence by $\mathrm{pH}$-metry for all investigated glasses (Fig. 3). The obtained results confirm the maximum extraction. Thus, the highest $\mathrm{pH}$ is provided by the ratio 0.025 and the difference between different types of glass is within the error range.

Thus, to estimate the alkali activity of glass powder at the beginning of cement hydration it is necessary to use the fraction $<0.063 \mathrm{~mm}$ in the amount corresponding to the ratio glass/water 0.025 . The alkali activity of glass powder in water (expressed by $\mathrm{pH}$ ) is equal to 11.2 regardless of glass type at $\mathrm{Na}_{2} \mathrm{Oeq}$ content of $13-14 \%$.

As it was mentioned above, alcohol is more suitable for extraction while determining glass alkali activity, because it excludes the cement hydration. The same assertion concerns other active additives (Table 4). 
Victor Shevchenko et al.

Table 3

Dependence of hydroxyl groups concentration and share of surface ions on glass/water ratio

\begin{tabular}{|c|c|c|}
\hline Ratio glass*/water & Concentration of hydroxyl groups $\left(C_{O H}^{-} \cdot 10^{-3}\right), \mathrm{mol} / \mathrm{l}$ & Share of surface ions, $\%$ \\
\hline 0.005 & 0.15 & 8.3 \\
\hline 0.025 & 0.35 & 3,3 \\
\hline 0.050 & 0.40 & 2.0 \\
\hline 0.075 & 0.45 & 1.7 \\
\hline 0.100 & 0.45 & 1.2 \\
\hline 0.125 & 0.50 & 1.1 \\
\hline
\end{tabular}

Note: *brown glass, sieve $<0063 \mathrm{~mm}$

Table 4

Dependence of $\mathrm{pH}$ on the type of extracting agent for different materials

\begin{tabular}{|l|c|c|}
\hline \multicolumn{1}{|c|}{ Materials* } & $\mathrm{pH}$ in water** & $\mathrm{pH}$ in alcohol*** \\
\hline Cement & 13.2 & 8.4 \\
\hline Colorless glass & 11.4 & 11.9 \\
\hline Brown glass & 11.1 & 12.3 \\
\hline Green glass & 11.2 & 11.8 \\
\hline Microsilica & 7.3 & 8.4 \\
\hline Fly ash & 13.2 & 8.4 \\
\hline
\end{tabular}

Notes: $*$ glass $/$ water $=1 / 40, * *$ water $(\mathrm{pH}=7.2), * * *$ alcohol $(\mathrm{pH}=7.5)$

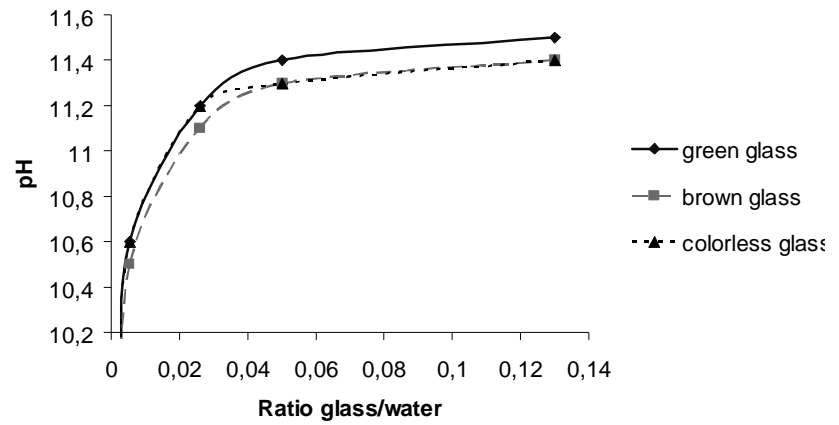

Fig. 3. Dependence of $\mathrm{pH}$ on glass/water ratio (pH-metry)

Cement has the highest $\Delta \mathrm{pH}$ value in water (Table 4) due to $\mathrm{Ca}(\mathrm{OH})_{2}$ formation, microsilica has the lowest $\Delta \mathrm{pH}$. Cement, microsilica and fly ash are inactive in alcohol. The reason is small content of alkali oxides in their compositions (about $1 \%$ ). At the same time glass (regardless of its type) shows high alkali activity in alcohol due to its high alkali content.

As it was mentioned above, in order to evaluate the effect of glass powder alkali content on the total alkali content of cement-glass mixture it is necessary to introduce the idea of alkali activity of all components. The alkali activity of cement-glass mixture $(\mathrm{Am})$ is a sum of $\mathrm{Na}_{2} \mathrm{Oeq}$ amount in every component per the quantitative amount in the composition. After determination of alkali activity of cement-glass mixture and having the allowable amount of Na2Oeq (according to PN-B 19707) we may determine the allowable amount of introduced glass powder [16].
It is known that alkali in the cement mortar has a positive effect on cement hydration, especially during preinduction period. Hence, while adding alkali component of the glass powder the hydration is promoted [10, 14]. However it concerns only cations first level, the amount of which is approximately $6 \%$ of total alkali content of glass [15]. Second level alkalis react with silica compounds of concrete fillers for a long time (ASR effect) and form the products capable to increase in their volume and destroy the concrete construction [2]. The example of alkaline factor effect may be the results of calculations at the beginning (first level) and end of hydration (second level) for some cement in mixtures with glass powder, Table 5.

The excess of $\mathrm{Na}_{2} \mathrm{Oeq}$ amount above $0.6 \%$ renders the use of glass powder as an additive to ordinary Portland cement impossible. The decrease in cement alkali content to $0.31-0.46 \%$ and holding content of glass alkali content at the level of $\mathrm{Na}_{2} \mathrm{Oeq} 13-14 \%$ allows to introduce $1.0-1.3 \%$ of glass powder relative to the cement weight. It should be noted that glass color does not affect the alkali activity.

Thus, while developing the new compositions of the cement composites in accordance with the proposed methodic, one can calculate the composite alkali activity at the beginning of the hydration and on conditions that all alkalis turn into active state. The information about composite alkali activity allows to predict its effect on the alkaline corrosion of the concrete constructions made of chosen blended cements. 
Table 5

Effect of alkaline factor on the alkali content of the cement-glass mixture

\begin{tabular}{|c|c|c|c|c|c|c|c|}
\hline \multirow{2}{*}{ References } & \multirow{2}{*}{$\begin{array}{l}\mathrm{Na}_{2} \mathrm{Oeq} \text { content } \\
\text { in cement, } \%\end{array}$} & \multirow{2}{*}{$\begin{array}{c}\mathrm{Na}_{2} \mathrm{Oeq} \\
\text { content in } \\
\text { glass, \% }\end{array}$} & \multirow{2}{*}{$\begin{array}{c}\text { GP } \\
\text { content, } \\
\% *\end{array}$} & \multicolumn{2}{|c|}{$\begin{array}{l}A m \text { of } \mathrm{Na}_{2} \mathrm{Oeq} \text { in } \\
\text { mixtures, } \%\end{array}$} & \multirow{2}{*}{$\begin{array}{l}\text { GP admissible } \\
\text { quantity, } \%\end{array}$} & \multirow{2}{*}{ Glass } \\
\hline & & & & $\begin{array}{l}\text { First } \\
\text { level }\end{array}$ & $\begin{array}{c}\text { Second } \\
\text { level }\end{array}$ & & \\
\hline $\begin{array}{c}\text { Caijun Shi et al., } \\
2005 \\
\end{array}$ & 0.63 & 13.28 & 20 & 0.19 & 3.16 & 0 & $\begin{array}{l}\text { Bottles } \\
\text { Clear }\end{array}$ \\
\hline \multirow{3}{*}{$\begin{array}{l}\text { Seung-Bum Park } \\
\text { et al., } 2004\end{array}$} & \multirow{3}{*}{0.66} & \multirow{3}{*}{14.11} & 10 & 0.12 & 2.00 & 0 & \multirow{3}{*}{$\begin{array}{l}\text { Bottles } \\
\text { Brown }\end{array}$} \\
\hline & & & 20 & 0.20 & 3.35 & 0 & \\
\hline & & & 30 & 0.28 & 4.69 & 0 & \\
\hline $\begin{array}{l}\text { Natan Schwarz } \\
\text { et al., } 2008\end{array}$ & 0.73 & 13.73 & 20 & 0.20 & 3.33 & 0 & Colorless \\
\hline \multirow{11}{*}{$\begin{array}{l}\text { Natan Schwarz } \\
\text { et al., } 2007\end{array}$} & \multirow{5}{*}{-} & \multirow{5}{*}{-} & 10 & 1.22 & 2.03 & 0 & \multirow{5}{*}{-} \\
\hline & & & 20 & 0.12 & 3.33 & 0 & \\
\hline & & & 30 & 0.27 & 4.63 & 0 & \\
\hline & & & 20 & 0.20 & 3.36 & 0 & \\
\hline & & & 30 & 0.28 & 4.67 & 0 & \\
\hline & \multirow{3}{*}{ - } & \multirow{3}{*}{13.88} & 10 & 0.12 & 2.04 & 0 & \multirow{3}{*}{ Brown } \\
\hline & & & 20 & 0.20 & 3.36 & 0 & \\
\hline & & & 30 & 0.28 & 4.67 & 0 & \\
\hline & \multirow{3}{*}{-} & \multirow{3}{*}{13.69} & 10 & 0.12 & 2.02 & 0 & \multirow{3}{*}{ Green } \\
\hline & & & 20 & 0.20 & 3.32 & 0 & \\
\hline & & & 30 & 0.27 & 4.62 & 0 & \\
\hline \multirow{3}{*}{$\begin{array}{l}\text { K.L. Lin et al., } \\
2009\end{array}$} & \multirow{3}{*}{0.42} & \multirow{3}{*}{0.45} & 10 & 0.02 & 0.42 & 6.00 & \multirow{3}{*}{$\begin{array}{c}\text { Glass } \\
\text { TFT-LCD }\end{array}$} \\
\hline & & & 20 & 0.02 & 0.42 & - & \\
\hline & & & 30 & 0.02 & 0.43 & - & \\
\hline \multirow{3}{*}{$\begin{array}{l}\text { V. Shevchenko, } \\
2012\end{array}$} & \multirow{3}{*}{0.46} & 13.52 & \multirow{3}{*}{0.50} & 0.03 & 0.52 & 1.07 & $\begin{array}{c}\text { Bottles } \\
\text { Colorless }\end{array}$ \\
\hline & & 13.89 & & 0.03 & 0.52 & 1.04 & $\begin{array}{l}\text { Bottles } \\
\text { Brown }\end{array}$ \\
\hline & & 13.13 & & 0.03 & 0.52 & 1.10 & $\begin{array}{l}\text { Bottles } \\
\text { Green }\end{array}$ \\
\hline \multirow{3}{*}{$\begin{array}{l}\text { Xie Z. et al., } \\
2002\end{array}$} & \multirow{3}{*}{0.67} & \multirow{3}{*}{-} & 4.00 & 0.05 & 0.83 & - & \\
\hline & & & 7.00 & 0.08 & 1.44 & - & Glass* \\
\hline & & & 10.00 & 0.10 & 1.72 & - & \\
\hline $\begin{array}{c}\text { Guohua Chen } \\
\text { et al., } 2002\end{array}$ & 0.31 & - & 1.30 & 0.02 & 0.40 & - & Glass* \\
\hline
\end{tabular}

Note: * introduction of glass into the raw material during cement production.

\section{Conclusions}

The catalytic activity of alkaline component of glass powder on the acceleration of cement hydration during pre-induction period indicates that glass is an active additive during this period. However for the samples with glass the maximum rate of heat release during post-induction period is achieved by $1.5 \mathrm{~h}$ later than for the control samples. This fact reveals the retarding action of glass additives during post-induction period.

While comparing the calculated and experimental methods of alkali activity determination of the separate components and the blended cements it should be noted that both methods show the dependence of alkali activity of the composition on specific alkali activity of its components. During design period the calculated method allows to estimate the effect of alkaline factor on the total alkali content on the basis of known chemical composition of every component. While determining alkali activity by experimental method it is better to use ethyl alcohol as the extracting agent.

\section{References}

[1] Myasnikova E., Gumen V., Saldugey M., Sanitski M. et al.: Theoria Cementa. Budivelnyk, Kiev 1991.

[2] Shevchenko V.: Glass Phys. Chem., 2012, 38, 466.

[3] Ismail Z. and Al-Hashmi E.: Waste Manage., 2009, 29, 655. 
[4] Shi C., Wu Y., Riefler C. and Wang Y.: Cement Concrete Res., 2005, 35, 987.

[5] Schwarz N. and Neithalath N.: Cement Concrete Res., 2007, 38, 429.

[6] Shevchenko V. and Kotsay G.: Chem. Chem. Technol., 2014, 8, 189.

[7] Shayan A. and Xu A.: Cement Concrete Res., 2004, 34, 81.

[8] Taha B. and Nounu G.: Constr. Build. Mater., 2008, 22, 713.

[9] Schwarz N., Cam H. and Neithalath N.: Cement Concrete Res., 2008, 30, 486.

[10] Kurdovski V.: Chemia Cementu I Betonu. Polski Cement, Krakow 2010.

[11] Chatterjee A.: [in:] Ghosh S. (Ed.), Advances in Cement Technology. Pergamon Press, Oxford 1983, 40.

[12] Jawed I. and Skalny J.: Cement Concrete Res., 1978, 8, 37.

[13] Yatchyshyn J.: Fizyka I Khimiya Skla. Beskud Bit, Lviv 2008.

[14] Shevchenko V. and Svierad V.: Chem. Chem. Technol., 2007, $1,179$.

[15] Shevchenko V. and Kotsay G.: Glass Phys. Chem., 2015, 5, 634.
[16] Shevchenko V. and Kotsay G.: J.Civil. Eng. Environ. Arch., XXXII, 403.

Received: February 22, 2016 / M arch 24, 2016 /

Accepted: J une 14, 2016

\section{ЛУЖНИЙ ЧИННИК В ЦЕМЕНТАХ З ДОБАВКАМИ СКЛЯНОГО ПОРОШКУ}

Анотація. В роботі досліджено вплив лужної складової скляного порошку на загальний луговміст цементноскляної суміші, який обмежений стандартами. Для иього були використані рН-метрія, класичний метод титрування та різні екстрагенти. Використовуючи експериментальні та розрахункові методи визначення лужної активності скляного порошку, можна проектувати хімічний склад иементних композитів, які б відповідали стандартним вимогам за загальним луговмістом.

Ключові слова: лужний чинник, Портланд иемент, иементно-скляна суміш, скляний порошок, екстракція лужний йонів. 